\title{
Redesigning MGMT 4010S: Creating A Cause Of Social Responsibility And Social Justice
}

Cary A. Caro, Ph.D., Xavier University of Louisiana, USA

Kolby Lirette, Louisiana State University, USA

Myke Yest, Ph.D., CFA, Tulane University, USA

\begin{abstract}
As business organizations face more and more scrutiny for poor leadership practices, American business schools have come under more pressure to prepare students to enter organizations with an understanding of and an appreciation for quality leadership. This manuscript focuses on the introduction of a service-learning project to a Senior Leadership Seminar course at a small university in Louisiana. This manuscript describes the impetus for change, including wanting to establish a method for students to actively engage in the principles of leadership, the course and project objectives, the measurement of those objectives, and the lessons learned through several iterations of the course. This paper is designed to provide a guide for future practitioners to integrate service learning into their courses, and to provide an outline of how it can be done through a senior seminar course.
\end{abstract}

Keywords: Service-Learning; Active-Learning; Leadership; Leadership Seminar; Course Project

\section{INTRODUCTION}

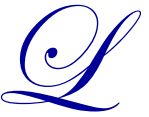

eadership can be seen as both an art and a science (Daft, 2008). There are "scientific" principles such as leadership theory that must be learned and aggressively debated in order for students to truly understand the underlying principles of leadership. Conversely, leadership can be viewed as an art, where developing cognitive characteristics, values, and a moral compass are inherent to an individual's evolution. Like learning to draw, paint, or sketch, an individual cannot learn the artistic value of leadership through a textbook; rather, an individual must have the opportunity to explore and shape their experience, so that those qualities can develop over the course of time.

Leadership, in its very nature is very abstract and versatile. There is the belief that leadership is an inherent quality; one that all individuals are born with. Borrowed from the Hopi Native American tribe, "We are the ones we have been waiting for," was a definition of leadership used during the Civil Rights movement. This was used to imply that leadership was an internal process in which anybody could partake (Mathews, 1996). Manning and Curtis (2012) define leadership as the deeds and ideas that individuals use to influence the behavior of others. Just as the definition can provide a myriad of responses, so too the debate on how to best teach leadership can evoke a multitude of best practices.

According to Gardner (1990, p.1), "Leaders cannot be thought of apart from the historic context in which they arise...they are an integral part of the system, subject to the forces that affect the system." To think of leadership development in this context almost forces leadership education to adapt the experiential learning principles described by Kolb. Kolb (1984) concluded that individuals learn best when they are able to internalize new concepts. The four-step cycle to experiential learning includes concrete experience, reflective observation, abstract conceptualization, and active experimentation. For a soft skill such as leadership, however, the academic opportunities for active experimentation are often limited to a case study, a term paper, or some other course-based application of their knowledge. 
Building on the theoretical principles introduced by Kolb, the focus of this paper is to describe the development and integration of an active-learning project into a senior leadership seminar class. The increased importance of moral and ethical leadership in the business world in recent years was a catalyst that led to the need to revitalize the course and provide students with the opportunity to explore and develop their own leadership behavior. Engaging students in discussions and reflections on the theoretical principles as presented in a textbook were not enough to help students develop, and maximize, their leadership potential. In addition to describing the project and the impetus for change, this manuscript will explore the important individual and departmental concerns that must be considered when designing a course curriculum, and present the outcomes and objectives for such course design. Finally, this manuscript will focus on the lessons learned in hopes that it will allow future practitioners the opportunity to apply and adapt this methodology to their own institutional needs.

\section{THE IMPETUS FOR CHANGE}

Senior leadership seminar is a four-thousand level course that is available to graduating seniors in the management curriculum. Through topical readings, students analyze leadership concepts, participate in class discussions, and engage in reflective writing, all of which are appropriate to help form a conscious understanding of leadership practices. The mission and vision of the Division of Business, however, called for students to develop into "tomorrow's socially responsible leaders." In a review of the current curriculum, it was noted that while there was ample opportunity for the discussion of moral and ethical behavior, the opportunity to practice and experiment with moral and ethical actions was lacking. The project, then, ensures alignment and fit with the Division's mission, vision, and values, and meets the Division's desire to increases the number of courses that expose students to issues that present an opportunity to understand social responsibility, social justice, and ethical behavior. In short, consensus was reached that in order for students to develop into "socially responsible leaders," they needed an opportunity to experience what socially responsible leadership meant.

The senior leadership seminar course was targeted for change as it provided an engaged student body and a natural fit for an experiential learning exercise in leadership. Further, the course covered the "scientific" side of leadership, with readings on the theoretical framework of leadership, discussions on the great leaders in world history, and discussion on the various fads in leadership development. What the course lacked was the opportunity for students to gauge their own leadership qualities and design a development plan to address their inefficiencies. Understanding the importance and impact of active learning principles in the learning cycle, the decision was made to integrate a service-learning project that forced students to engage with the community, by identifying a social problem, and working with a team to address, at least in part, solving the social or moral problem.

\section{THE PROJECT}

The focus of the project is to design, develop, implement, and evaluate a semester-long activity through which students are forced to experience the leadership process first-hand, while they read and reflect on the writings of other influential leaders. Working individually, students form teams of their peers (who are not in the class) and identify a social or moral problem in the community or on campus that they wish to address. Students are then responsible for leading their group to create an action plan that will address the problem, for carrying out their plan to completion, and for creating a course portfolio that documents their work and personal growth throughout the semester. In effect, the project aims to incite change (and thus, social responsibility) through citizenship, controversy, and self-awareness. The course goals are stated as follows:

- $\quad$ To allow students to develop and articulate a functional understanding of leadership.

- To provide students with a strong mechanism for integrating coursework into authentic leadership experiences.

- $\quad$ To further develop a student's leadership knowledge and skills.

- To extend a student's practical leadership experience and her/his understanding and capacity to independently manage the challenges and uncertainties associated with leadership.

- $\quad$ To allow students to lead a group of people to accomplish or create something. 
Further, the project goals are stated as, "upon completion of the project, students will:"

- $\quad$ Document their service experience and leadership growth in a course portfolio.

- $\quad$ Define a functional and personal meaning for leadership.

- $\quad$ Participate in 30 hours of community service.

- $\quad$ Outline a leadership development plan to help them grow as a leader.

- Identify their personal strengths and opportunities for growth as a young leader.

There are three main facets to the project that students must complete. The first is the project proposal. The proposal is designed to capture the essence of the project and illustrate to the professor the importance of the social problem that has been identified by the student. In the proposal, students are responsible for communicating the problem, including why the issue is important to them, what impact the issue has on the local or global community, and why finding a solution to the problem is of great importance. Students are required to read and report from the scholarly literature and find evidence of the problem in the national or local media. Students are also required to present and outline their specific initiative that they will be undertaking over the course of the semester (their solution to the problem), identify the achievable outcomes and goals for the project, and present a plan to monitor their progress and evaluate success. Concomitantly, after a period of self-reflection and personal study, students must identify their personal leadership development goals and outline how the project will allow them to evolve and develop as a leader. Finally, students must develop metrics for their project that help them to define success in terms of their project outcomes.

The second main element for students is actually conducting the project. To accomplish this, students are given the autonomy to find a community partner that will help them reach their goals. As part of finding a partner, students also have to identify an individual within the organization that can serve as a site supervisor, who assimilates the students into the organization, provides direction and feedback to their performance, and secures any necessary resources that are required to complete the project. The site supervisor agrees to act as a liaison between the student and the professor, and provides evidence that the student has completed the project. Examples of community partners and projects have include: United Way and the completion of a blood drive; a national chain grocery store and a community book drive; and, a local fitness center and an awareness campaign about childhood obesity and disease.

The final aspect of the project is completion of the project portfolio, where students will provide evidence of their work over the course of the semester. Students are given full creative freedom to create their portfolio. Previous portfolios have included everything from scrapbooks to home movies as a documentary of their work. The final portfolio has several required elements. Among those are: a description of their project; a definition of their achievable project outcomes along with a commentary on whether they were achieved; a reflection on their individual leadership development outcomes and their progress over the course of the project; and, an evaluation of the impact that their project had on the problem identified. In addition, students are to provide weekly personal reflections on their experiences that address what they have learned, the challenges they faced, and any breakthroughs realized. They must also provide a longer, descriptive narrative on their experience with the overall project. The project culminates with the student presenting their project at a Division of Business-sponsored event.

\section{MEASUREMENT}

There are two important avenues to measure success of this course. On an individual level, student projects are not graded by the impact that they have in the community, as some students will have projects that fail to meet their stated outcomes and goals. Rather, students are graded on their personal narratives, reflections, and on their leadership evolution over the course of the project. This is not to discount the importance of students successfully completing the project; however, the goal for the project is for students to understand their approach to leadership and develop their leadership skills. Sometimes, students learn to lead by conducting a very successful project. Other times, students develop great leadership skills by understanding the source of their failures in leading a group of people. Therefore, it is important for professors to remember that while project completion and impact are crucial aspects of the course, the personal development and growth of the student really is paramount. 
The second avenue of measurement comes in the success of the course with respect to course outcomes and objectives. Course goals are measured as follows:

\begin{tabular}{|l|l|}
\hline \multicolumn{1}{|c|}{ Course Goal } & \multicolumn{1}{|c|}{ Measurement } \\
\hline Develop a functional understanding of leadership. & $\begin{array}{l}\text { Students prepare a final paper that outlines how leadership is } \\
\text { defined and developed individually. }\end{array}$ \\
\hline $\begin{array}{l}\text { Provide students with a strong mechanism for integrating } \\
\text { coursework into authentic leadership experiences. }\end{array}$ & $\begin{array}{l}\text { Students write reflective narratives that challenge them to link } \\
\text { their experiences to the theory presented to them in class. }\end{array}$ \\
\hline Further develop a student's leadership knowledge and skills. & $\begin{array}{l}\text { Students complete a survey at the onset and at the end of the } \\
\text { semester. Results are compared. }\end{array}$ \\
\hline $\begin{array}{l}\text { Extend a student's practical leadership experience and her/his } \\
\text { understanding and capacity to independently manage the } \\
\text { challenges and uncertainties associated with leadership. }\end{array}$ & Achieved and documented through the course project. \\
\hline Lead a group of people to accomplish or create something. & Achieved and documented through the course project. \\
\hline
\end{tabular}

\section{LESSONS LEARNED}

It is important for future practitioners to understand that a project of this magnitude requires a great amount of work on the part of the professor. While the site supervisor shares much of the burden in leading the project, the professor for the course is still ultimately responsible for providing the guidance and assistance to get the project off the ground. A great amount of time is spent consulting, advising, and encouraging students with respect to the project; therefore, it is recommended that enrollment for the course to be capped at a maximum of twenty-five students. An alternative to capping the number of students is for the class to be divided into groups where each group will be responsible for a project. However, this may lead to a situation where students become passive in the process because other students take the lead and initiative, or students simply are not engaged in the project because it is not their own.

Aligning fit between the project and the division or school of business is of utmost importance. This course is offered to senior management majors who have completed the majority of their management curriculum. Therefore, these students not only develop their leadership skills, but also apply their business management skills, which have been acquired over the previous three to four years. Site supervisors are great resources; however, the student must have the ability to manage the project independently. Further, the project should fit within the mission and vision of the division or school. Therefore, it is important to secure the approval of the chair or dean as part of the process.

Finally, understanding the outcomes of the project is of great importance to the professor undertaking the course. To this end, adjustments have been made to the grading rubric to ensure that students who develop their leadership skills and evolve as leaders as a result of this course, but have projects that fail due to uncontrollable circumstances, have an opportunity to score highly on the project. While some students will have a project fail due to a lack of effort and desire, there is always a segment of the student population that will exert their full potential, apply all of their resources, and not have a project that meets the end goals. These students are then able to reflect on what they did wrong and create narratives that illustrate why their projects failed. These students experience the same level of growth, or potentially more, than those with successful projects.

\section{CONCLUSIONS}

Redesigning the senior leadership seminar has proven to be a worthwhile initiative for the Division of Business. Students are now able to learn the science of leadership, while developing the art of leadership through active learning and service-learning. For educators, this is a project that allows for a creative approach to leadership development, and can have a meaningful impact on the community. Students are able to explore their passions, make judgments about social issues, and develop an understanding of social justice, moral issues, and the power and importance of raising awareness through action.

As more schools adopt courses that integrate service and active learning principles into the teaching of leadership, further research opportunities will arise regarding the development of best practices, the development of 
individual leadership characteristics, and the achievement of the evolution of the young scholar through the application of learned knowledge. This project sets the stage for future business leaders to assess their current leadership inventory and to formulate a plan to develop and enhance those skills. Further, it synergizes the theoretical principles of leadership and the recognition of moral outcomes so that students can freely maximize their personal potential. In the end, projects such as this should challenge students to think critically about the world around them and force students to respond with vigor to the challenges that they perceive in their communities. It is the hope that one day these students can do the same for the organizations in which they build their careers.

\section{AUTHOR INFORMATION}

Cary A. Caro, Ph.D., Xavier University of Louisiana, 1 Drexel Dr., New Orleans, LA 70125. Cary Caro is an Assistant Professor of Management at Xavier University of Louisiana and the Managing Editor of the American Journal of Business Education. E-mail: ccaro@xula.edu (Corresponding author)

Kolby Lirette, Louisiana State University. Kolby Lirette is a graduating senior at Louisiana State University.

Myke Yest, Ph.D., CFA, Tulane University, A.B. Freeman School of Business, New Orleans, LA 70118. Myke Yest is a Professor of Practice in Finance at the A.B. Freeman School of Business at Tulane University. E-mail: myest@tulane.edu

\section{REFERENCES}

1. Daft, R. L., \& Lane, P. G. (2008). The Leadership Experience (5th ed.). Mason, OH: South-Western Cengage Learning.

2. $\quad$ Gardner, J. W. (1990). On Leadership. New York, NY: Free Press.

3. Kolb, D. A. (1984). Experiential Learning: Experience as the Source of Learning and Development. Englewood Cliffs, NJ: Prentice-Hall.

4. Manning, G., \& Curtis, K. (2011). The Art of Leadership (4th ed.). Columbus, OH: McGraw-Hill Companies.

5. Mathews, D. (1996). Is There a Public for Public Schools? Dayton, OH: Kettering Foundation. 
NOTES 